\title{
Antioxidant activities of essential oils of Clausena anisata (Rutaceae) and Plectranthus glandulosus (Labiateae), plants used against stored grain insects in North Cameroon
}

\author{
Augustin GOUDOUM ${ }^{1 *}$, Léonard Simon NGAMO TINKEU ${ }^{2}$, Martin Benoît \\ NGASSOUM $^{1}$ and Carl Moses MBOFUNG ${ }^{1}$ \\ ${ }^{1}$ National High School of Agro Industrial Sciences, P.O. Box 455 Ngaoundéré, Cameroon. \\ ${ }^{2}$ Faculty of Sciences, Department of Biological Sciences, P.O. Box 454 Ngaoundéré, Cameroon. \\ *Corresponding author, E-mail: goudoumaugust@gmail.com; Phone: 00237 $77171162 / 94499511$
}

\begin{abstract}
This study was carried out to evaluate the overall antioxidant capacity of the essential oils of the leaves of Clausena anisata (Rutaceae) and Plectranthus glandulosus (Labiateae), commonly used in the traditional method of grain storage in the northern part of Cameroon. Towards this objective, the co-oxidation of $\beta$ carotene as well as the reducing power, the radical scavenging capacity and the conjugated dienes profile of the essential oils during storage for a period of 10 days at $28 \pm 2.2{ }^{\circ} \mathrm{C}$ and $65 \pm 5.7 \% \mathrm{RH}$ were determined. The least concentration necessary to prevent $50 \%$ oxidation $\left(\mathrm{EC}_{50}\right)$ of $\beta$-carotene was found to be $6.53 \mathrm{mg} / \mathrm{l}, 5.84 \mathrm{mg} / \mathrm{l}$ and $524 \mu \mathrm{g} / \mathrm{l}$ respectively for $C$. anisata, $P$. glandulosus and butylated hydroxytoluene (BHT) which was the control. On the other hand, the reducing power of the different oils in a decreasing order was found to be $P$. glandulosus $\left(\mathrm{EC}_{50}=2.41\right)>C$. anisata $\left(\mathrm{EC}_{50}=1.77 \mathrm{mg} / \mathrm{l}\right)$ while the $\mathrm{EC}_{50}$ of Scavenging abilities were 2.66 and $3.02 \mathrm{mg} / \mathrm{l}$ for $C$. anisata and $P$. glandulosus respectively. Based on the conjugated dienes profile, the essential oils showed higher antioxidant activity compared to Butylated hydroxytoluene (BHT) activity. The effective time $\left(\mathrm{ET}_{50}\right)$ of the formulation ranging from 300 to $1000 \mathrm{ppm}$ varied from 2 to 8 days for C. anisata and from 3 to 11 days for P. glandulosus. For the control (BHT), the effect varied from 5 to 15 days at an exposition temperature of $50{ }^{\circ} \mathrm{C}$.

(C) 2009 International Formulae Group. All rights reserved.
\end{abstract}

Key words: Antioxidant activity; Clausena anisata; Plectranthus glandulosus; Stored products; Scavenging ability; Reducing power.

\section{INTRODUCTION}

Quality in relation to health is of major concern in the food industry (CIRAD, 2007). As consequence, actors at difference stages of the food chain are constantly preoccupied with the need to ensure that food produced for consumers is safe. In this respect, and with particular reference to post harvest storage of crops, the use of certain chemicals is fast being discouraged as current research results are increasingly demonstrating their toxic effects to man and the environment (White et Leesch, 1995; Regnault-Roger et al., 2002;
CIRAD, 2007). To remedy this situation, alternative non toxic methods capable of protecting grains from insect attack is being encouraged and searched for.

In the northern part of Cameroon, peasants have the habit of using local aromatic plants in their granaries while filling them up with grain as a means of protecting them against insect attack during storage (Anonyme, 2004). As a matter of fact, several publications in the literature demonstrate the biodegradability and anti-insect effect of several aromatic compounds and as such 
suggest their potential use as an alternative to the conventional chemical insecticides generally used in the control of the stored grain pests. The essential oils of these aromatic plants contain bioactive compounds with diverse biological roles. In addition to their anti-insect potential for example, they also exhibit other biological activities because of their high antioxidant potential and their action on free radicals.

Earlier studies in our laboratory aimed at determining the duration of activity of some essential oils as sources of antioxidants for use in grain storage had revealed a maximum period of efficiency of 10 days for grains and two weeks for flour made from the grains (Goudoum et al., in press). After this point, it was equally observed that the stored product possessed a rancid flavour. Given that grains stored by this method are often consumed without any noticeable side effects, the question of interest is to know the residual antioxidant activity of the essential oils that are consumed with such foods. The present study therefore was carried out to evaluate the antioxidant potential of the residues of essential oils of $C$. anisata and $P$. glandulosus at the pint of diminished efficiency when used as for grains storage.

\section{MATERIALS AND METHODS Insecticidal products tested}

The essential oils tested were obtained by hydrodistillation of dried leaves of $C$. anisata and fresh ones of $P$. glandulosus with a Clevenger type apparatus during 4 hours. Before the distillation stage, leaves of the aromatic plants previously dried under shade with the exclusion of direct sunlight, were cut in small pieces before introducing into the reactor. Essential oils collected as well as the solution of Butylated Hydroxytoluene (BHT) serving as the control were put into labelled tubes and left in a cupboard for 10 days under controlled conditions of temperature and humidity ( T: $28 \pm 2.2{ }^{\circ} \mathrm{C}$; RH: $65 \pm 5.7 \%$ ). The duration of 10 days was chosen to correspond to time limit earlier shown to be the critical point for diminishing efficiency of insecticidal activity of essential oils on the maize grains and flour. For the determination of antioxidant activity, essential oils concentrations ranging from 1, 5, 10, $15 \mathrm{mg} / \mathrm{l}$ were used while the conjugated dienes determination made use of concentrations ranging from 300 to $1000 \mathrm{ppm}$. As control, an amount of 0.1 to $1.5 \mathrm{mg} / \mathrm{l}$ of Butylated hydroxytoluene (BHT) was used.

Linoleic acid, $\beta$-carotene and 1, 1diphenyl-2-picrylhydrazyl (DPPH), BHT, Potassium ferricyanide, nitro blue tetrazolium (NBT), trichloroacetic acid (TCA), and ferric chloride were purchased from Prolabo (France). All other reagents were of analytical grade. Freshly produced corn oil was purchased from the market in Ngaoundéré town.

\section{Analysis of chemical composition of essential oils}

The GC/FID (Chromatographer Agilent HP-6890) was carried out with HP-5MS column (5\% phenyl methyl siloxane) with 30 $\mathrm{m}$ length and $250 \mu \mathrm{m}$ in diameter and $1 \mu \mathrm{m}$ of thickness. The carrier gas was hydrogen, the oven temperature was programmed from 40 to $230{ }^{\circ} \mathrm{C}$ with a rate of $5{ }^{\circ} \mathrm{C} / \mathrm{min}$ with a stay at $230{ }^{\circ} \mathrm{C}$ of $5 \mathrm{~min}$. The pressure of the carrier gas was $49.9 \mathrm{KPa}$ and the flux at $74.1 \mathrm{ml} / \mathrm{min}$. Quantification was carried out by percentage of peak area calculation. The identification of single compounds was performed by comparison of the retention-indices with reference data (Davies, 1990; Kouroussou et al., 1998)

\section{Antioxidant assay using a $\beta$-carotene- linoleate model system}

The cooxidation of $\beta$-carotene by essential oils was evaluated using the $\beta$ carotene-linoleate model system as described by Miller, 1971. Essentially, a solution of $\beta$ carotene was prepared by dissolving $2 \mathrm{mg}$ of $\beta$-carotene in $10 \mathrm{ml}$ of chloroform. Two millilitres of this solution were then introduced into a $100 \mathrm{ml}$ round bottom flask and the chloroform contained in it was removed using a rotary evaporator. To the remaining conjugated product, $40 \mu \mathrm{l}$ of purified linoleic acid, $400 \mathrm{mg}$ of Tween 40 emulsifier, and $100 \mathrm{ml}$ of aerated distilled water were added with vigorous shaking to form an emulsion. Aliquots $(4.8 \mathrm{ml})$ of this emulsion were then transferred into different test tubes containing different concentrations $(1 ; 5 ; 10 ; 15 \mathrm{mg} / \mathrm{l})$ of the essential oils $(0.2$ $\mathrm{ml}$ ). As soon as the emulsion was added to each tube, the zero time absorbance was 
measured at $470 \mathrm{~nm}$, using a Hitachi U-2001 spectrophotometer. Thereafter, the tubes were placed at $50{ }^{\circ} \mathrm{C}$, in a water bath for a period of two hours before re-measuring. A blank treatment, without $\beta$-carotene, served as the control for the spectrophotometric readings. The same procedure was repeated with the synthetic antioxidant, BHT, as positive control. Antioxidant activity was calculated using the following equation: \% AOA $=(\mathrm{As}$ 2H/Ai)*100; with: \%AOA, antioxidant activity; As, $\beta$-carotene content after $2 \mathrm{~h}$ of assay; $\mathrm{Ai}$, initial $\beta$-carotene content.

The $\mathrm{EC}_{50}$ value (mg essential oil $\mathrm{l}^{-1}$ ) was obtained by extrapolation from linear regression analysis. The reduction of antioxidant activity between the crude essential oils and those which were stored during a period of 10 days under ambient conditions were evaluated using the equation: $\% \mathrm{R}=$ $100 *(\mathrm{Tc}-\mathrm{Ts}) / \mathrm{Tc}$; with \% R: \% of reduction; Tc: antioxidant activity of crude oil; Ts: antioxidant activity of 10 days stored oil.

\section{Reducing power}

The reducing power was determined according to the method of Oyaizu (1986). According to this method, varying concentrations of essential oil $(1,5,10$ and 15 $\mathrm{mg} / \mathrm{l})$ were each dissolved in methanol $(2.5$ $\mathrm{ml})$ to which was then added $2.5 \mathrm{ml}$ of 200 $\mathrm{mM}$ sodium phosphate buffer ( $\mathrm{pH}$ 6.6) and 2.5 $\mathrm{ml}$ of $1 \%$ potassium ferricyanide, mixed and incubated at $50{ }^{\circ} \mathrm{C}$ for $20 \mathrm{~min}$. Followed by the addition of $2.5 \mathrm{ml}$ of $10 \%$ trichloroacetic acid (w/v). In order to measure the absorbance of the mixture, two millilitres of it were added to $5 \mathrm{ml}$ of deionised water and mixed with 100 $\mu 1$ of $0.1 \%$ ferric chloride. Readings were taken at $700 \mathrm{~nm}$ against a blank in a Hitachi U-2001 spectrophotometer. BHT served as the control antioxidant.

\section{DPPH radical-scavenging activity}

The antioxidant activity of the essential oils, based on the scavenging activity of the stable 1, 1-diphenyl-2-picrylhydrazyl (DPPH) free radical, was determined by the method described by Braca et al. (2001). Different concentrations of essential oils $(1,5,10$ and $15 \mathrm{mg} / \mathrm{l}$ ) were added to $3 \mathrm{ml}$ of a $0.004 \%$ $\mathrm{MeOH}$ solution of DPPH. Water $(0.1 \mathrm{ml})$ in place of the essential oils was used as control. The BHT was used for comparison.
Absorbance at $517 \mathrm{~nm}$ was determined after 30 min using a Hitachi U-2001 spectrophotometer, and the percent inhibition activity was calculated as:

$[(\mathrm{A} 0$ - A1)/A0]*100; where A0 was the absorbance of the control, and A1 was the absorbance of the extract/standard.

The $\mathrm{EC}_{50}$ of the essential oils was then determined by calculation and used for the evaluation of the reduction of antioxidant between the crude essential oils and those which were stored during 10 days in the ambient condition.

\section{Conjugated diene method}

The antioxidant activity was determined by the conjugated diene method (Frankel et al., 1994). Different quantities of essential oils $(0.06,0.3,0.6,0.9,1.2 \mathrm{mg})$ were mixed with $20 \mathrm{mg}$ of maize oil and $1 \mathrm{ml}$ of iso-octane. The mixture was homogenized in test tubes and placed in darkness at $50{ }^{\circ} \mathrm{C}$ to accelerate oxidation. After incubation, the absorbance of the mixture was measured every day during two weeks at $234 \mathrm{~nm}$ against a blank in a Hitachi U-2001 spectrophotometer. The antioxidant activity (AOA) was calculated as follows:

AOA $(\%)=[(\mathrm{DA} 234$ of control - DA234 of sample) / DA234 of control] $\cdot 100$.

A control consisted of iso-octan solution without essential oils added and the procedure was carried out as described above. An AOA value of $100 \%$ indicates the strongest antioxidant activity. $\mathrm{ET}_{50}$ value (ppm) is the effective time at which the antioxidant activity was $50 \%$ and was obtained by interpolation from linear regression analysis.

\section{Data analysis}

After an arcsine square root transformation, all data were analyzed using one way ANOVA with Stagraphic 5.0. Means of transformed data were compared and ranked using a Duncan's test at $\mathrm{P}<0.05$; means of untransformed data were recorded.

\section{RESULTS}

Chemical composition of essential oils of $C$. anisata and $P$. glandulosus

The result of the chemical analysis of the essential oils of $C$. anisata and $P$. glandulosus is presented in the table 1 . 
A total of 18 compounds with the rate above $1 \%$ were identified in the essential oil of $C$. anisata representing $95.12 \%$ of crude oil (Table 1). Sabinene, trans-linalool oxide, estragole, (E)-caryophyllene, $\beta$-copaene, $\alpha$ humulene, germacrene $\mathrm{D}$ and $(\mathrm{E})$-nerolidol were the major constituents $(71.73 \%)$ of the crude essential oil. This oil after 10 days storage corresponding to its remanence at $28 \pm$ $2.2{ }^{\circ} \mathrm{C}$ of temperature and $65 \pm 5.7 \%$ of relative humidity, had only $50 \%$ of the concentration of the major compounds remaining.

Table 1: Chemical composition obtained by GC/FID of the essential oils of crude and 10 days stored Clausena anisata and Plectranthus glandulosus from Cameroon.

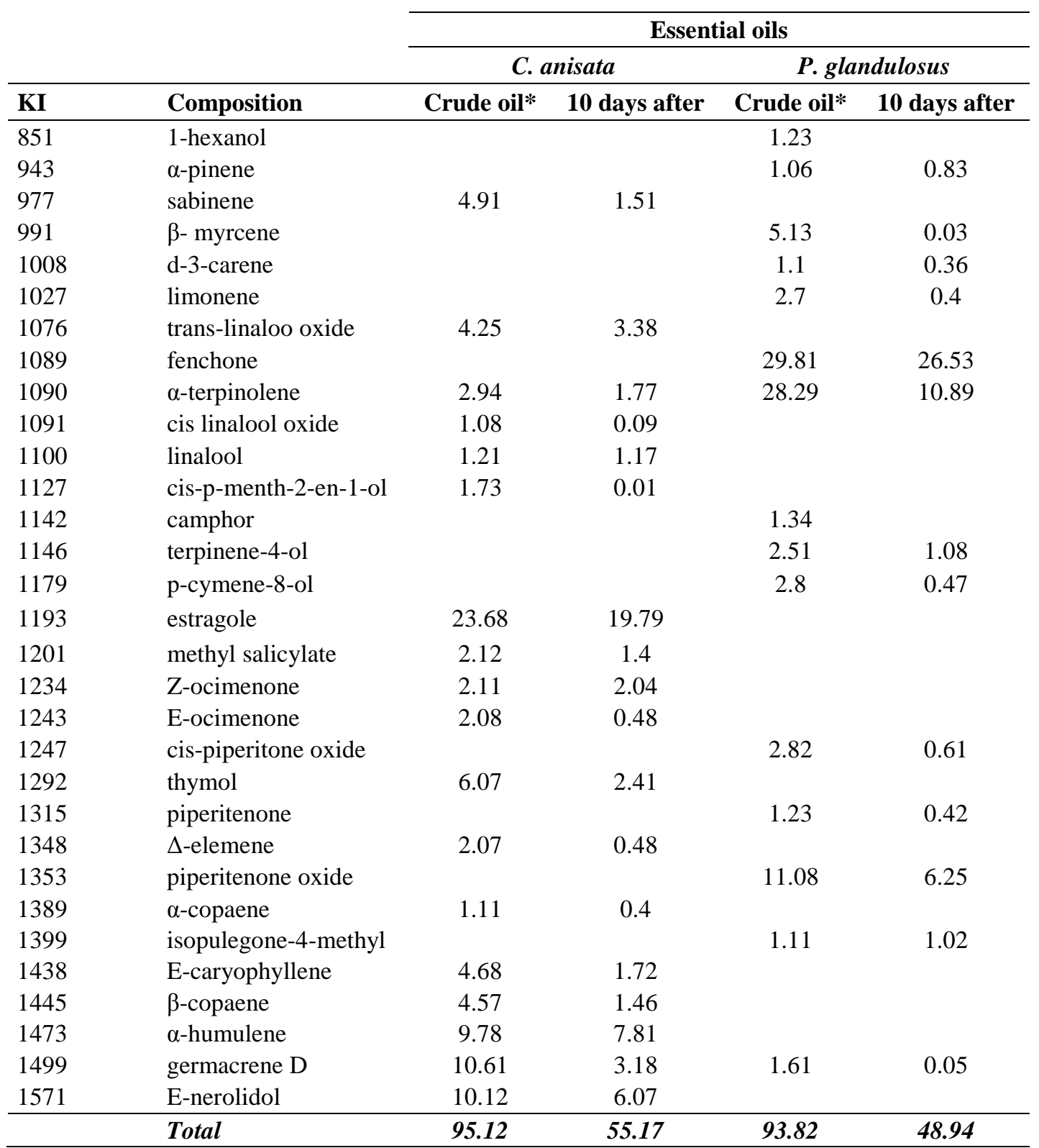

* The compounds of crude essential oils considered in this analysis were those having their rate above $1 \%$. 
A total of 15 compounds with the rate above $1 \%$ were identified in the essential oil of $P$. glandulosus (Table 1), where $\beta$-myrcene, limonene, fenchone, $\alpha$-terpinolene and piperitenone oxide represented $74.31 \%$ of the compounds in the crude oil. After 10 days of exhibition in the same conditions as previously described, the oil preserved 13 of its compounds with a reduction of their concentration to about $50 \%$.

\section{Antioxidant assay using a $\beta$-carotene- linoleate model system}

Table 2 shows the antioxidant activity of the essential oils of $C$. anisata and $P$. glandulosus as measured by the bleaching of $\beta$-carotene. The addition of essential oils of $C$. anisata and $P$. glandulosus and BHT at various concentrations prevented the bleaching of $\beta$-carotene to different degrees. The $\beta$-carotene in this model system undergoes rapid discoloration in the absence of an antioxidant. This is because of the coupled oxidation of $\beta$-carotene and linoleic acid, which generates free radicals. So, for concentrations in essential oil going from 1 to $15 \mathrm{mg} / \mathrm{l}$, the antioxidant activity varies from 15 to 86.82 and 18 to $89 \%$ respectively for $C$. anisata and $P$. glandulosus after 10 days of storage. However, no significant difference was observed between the antioxidant activities of the two essential oils. The essential oil of $C$. anisata stocked during 10 days, loses about 17 to $5 \%$ of its antioxidant efficiency of the crude one; and the one of $P$. glandulosus 15 to $6 \%$ for the concentrations going from 1 to $15 \mathrm{mg} / \mathrm{l}$. However, no significant difference is noted between the two categories of the same oil. The activity of the BHT varies from 20 to $96 \%$ for the concentrations going from 0.1 to $1.5 \mathrm{mg} / \mathrm{l}$. The $\mathrm{IC}_{50}$ that is the concentration that inhibits $50 \%$ of the antioxidant activity was $6.53 \mathrm{mg} / \mathrm{l}$ for $C$. anisata and $5.84 \mathrm{mg} / \mathrm{l}$ for $P$. glandulosus; for BHT, it was 10 times lower than those of essential oils $(524 \mu \mathrm{g} / \mathrm{l})$.

\section{Reducing power determination of essential oils}

Table 3 shows the reductive capabilities of essential oils compared to BHT. For the measurements of the reductive ability, we investigated the $\mathrm{Fe}^{3+} / \mathrm{Fe}^{2+}$ transformation in the presence of essential oils, using the method of Oyaizu (1986). The results of the table show that the studied essential oils are able to inhibit the reducing power that would occur without their presence in the reaction. This reduction varies from 14 to $81 \%$ for the two essential oils for the concentrations going from 1 to $15 \mathrm{mg} / \mathrm{l}$ for the storage one. The storage oil of $C$. anisata

Table 2: Antioxidant activity of crude and 10 days stored essential oils of Clausena anisata and Plectranthus glandulosus in $\beta$-carotene-linoleate system.

\begin{tabular}{|c|c|c|c|c|c|c|}
\hline \multicolumn{7}{|c|}{ Antioxidant activity (\%) } \\
\hline \multirow{6}{*}{ C. anisata } & $\mathrm{C}(\mathrm{mg} / \mathrm{l})$ & Crude oil & 10 day after & & $\%$ Reduction & $\mathrm{EC}_{50}(10$ days $)$ \\
\hline & 1 & $18.36 \pm 0.21$ & $15.14 \pm 1.21$ & $\mathbf{a}$ & 17.53 & $6.53 \mathrm{mg} / \mathrm{l}$ \\
\hline & 5 & $42.26 \pm 0.16$ & $38.27 \pm 0.98$ & $\mathrm{~b}$ & 9.44 & \\
\hline & 10 & $75.86 \pm 0.05$ & $69.60 \pm 1.03$ & $\mathrm{c}$ & 8.25 & \\
\hline & 15 & $91.61 \pm 0.22$ & $86.82 \pm 1.01$ & $\mathrm{~d}$ & 5.22 & \\
\hline & $F(3,4)$ & $69155.75 * * *$ & $17080.41 * * *$ & & & \\
\hline \multirow{5}{*}{ P. glandulosus } & 1 & $22.43 \pm 0.12$ & $18.87 \pm 1.00$ & $\mathrm{a}$ & 15.87 & $5.84 \mathrm{mg} / \mathrm{l}$ \\
\hline & 5 & $49.70 \pm 0.43$ & $42.80 \pm 1.22$ & $\mathrm{~b}$ & 13.88 & \\
\hline & 10 & $77.11 \pm 0.54$ & $72.97 \pm 0.88$ & $\mathrm{c}$ & 5.70 & \\
\hline & 15 & $95.77 \pm 0.47$ & $89.71 \pm 0.97$ & $\mathrm{~d}$ & 6.32 & \\
\hline & $F(3,4)$ & $11276.82 * * *$ & $112002.31 * * *$ & & & \\
\hline \multirow{5}{*}{ BHT } & 0.1 & $21.81 \pm 0.37$ & $20.88 \pm 1.07$ & $\mathrm{a}$ & 4.26 & $524 \mu \mathrm{g} / \mathrm{l}$ \\
\hline & 0.5 & $45.89 \pm 0.22$ & $45.70 \pm 0.85$ & $\mathrm{~b}$ & 0.41 & \\
\hline & 1 & $80.59 \pm 0.35$ & $78.59 \pm 0.77$ & $\mathrm{c}$ & 2.48 & \\
\hline & 1.5 & $96.64 \pm 0.09$ & $96.40 \pm 0.58$ & $\mathrm{~d}$ & 0.25 & \\
\hline & $F(3,4)$ & $27916.76 * * *$ & $38271.20 * * *$ & & & \\
\hline
\end{tabular}

$\mathrm{EC}_{50}$ value is the effective concentration at which the absorbance 0.5 for inhibition activity. $* * *=$ Significant at $1 \%$, Mean values followed by the same letter in the same column do not differ significantly at $\mathrm{P}<0.0001$ (Duncan's test). 
Table 3: Reducing power of essential oils of crude and 10 days storage Clausena anisata and Plectranthus glandulosus.

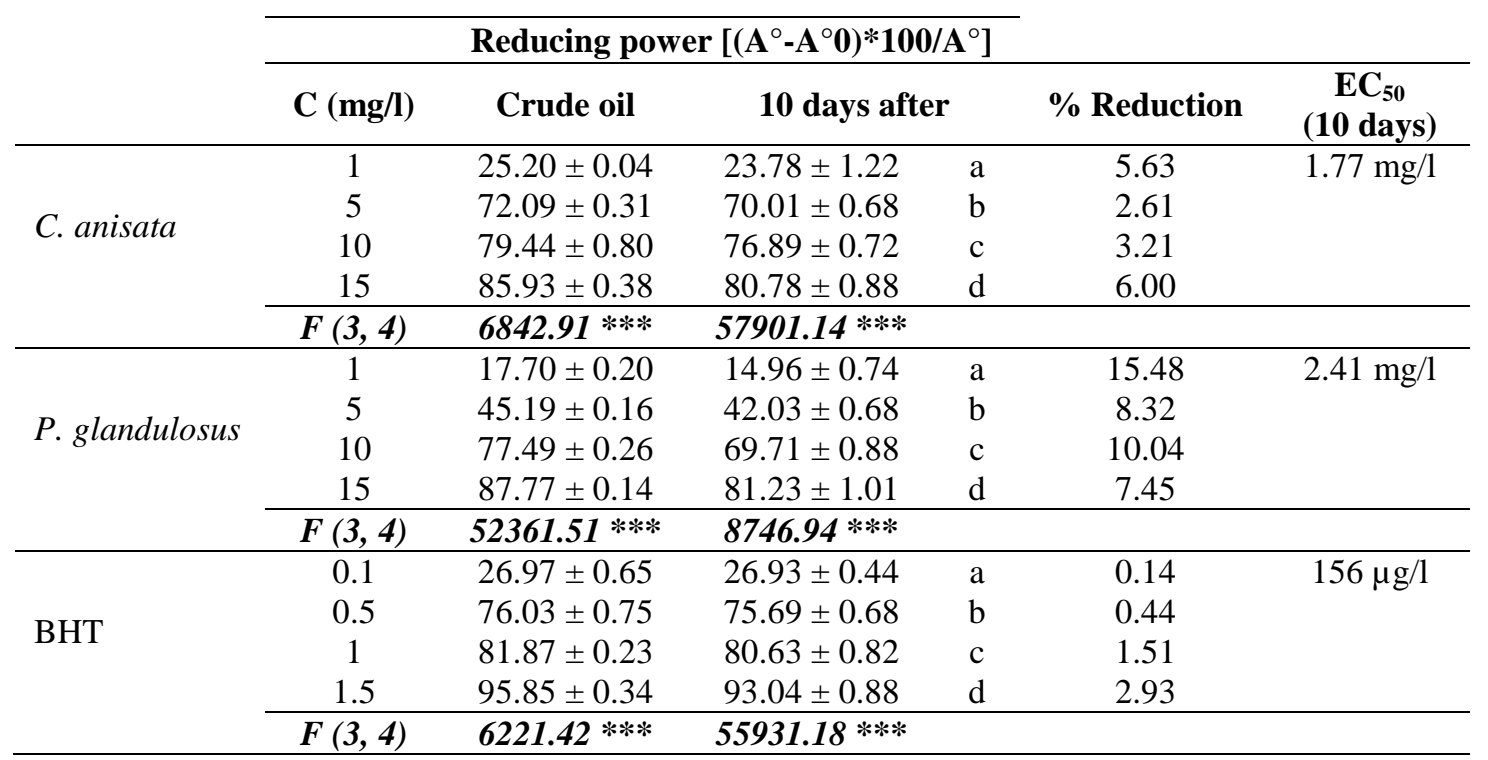

$\mathrm{EC}_{50}$ value is the effective concentration at which the absorbance was 0.5 for reducing power. $* * *=$ Significant at $1 \%$.. Mean values followed by the same letter in the same column do not differ significantly at $\mathrm{P}<0.0001$ (Duncan's test).

lost from 5 to $2 \%$ of its reducing power efficiency compared to the crude one; and that of P. glandulosus 10 to $7 \%$ for the concentrations going from 1 to $15 \mathrm{mg} / \mathrm{l}$. However, no significant difference was noted between the two categories of the same oil. Whereas for the control (BHT), it goes from 27 to $93 \%$ for concentrations going from 0.1 to $1.5 \mathrm{mg} / \mathrm{l}$. $\mathrm{EC}_{50}$, which is the concentration that reduces $50 \%$ of the reducing power of the test mixture, was $1.77 \mathrm{mg} / \mathrm{l}$ for $C$. anisata and $2.41 \mathrm{mg} / \mathrm{l}$ for $P$. glandulosus; the one of the BHT is of $154 \mu \mathrm{g} / \mathrm{l}$. There was no significant difference between the $\mathrm{EC}_{50}$ of the two studied essential oils.

\section{DPPH radical-scavenging activity}

The studied essential oils perfectly inhibited the free radical DPPH. C. anisata exposed for 10 days, inhibited 11 to $60 \%$ of radical DDPH contained in the solution, whereas $P$. glandulosus inhibited from 32 to $53 \%$ of DPPH for concentrations between 1 to $15 \mathrm{mg} / \mathrm{l}$. From the concentration of $10 \mathrm{mg} / \mathrm{l}$ to $15 \mathrm{mg} / \mathrm{l}$, the inhibition rate was the same for the two essential oils. To compare with the crude oils, one notes a reduction in the rate of capture of DDPH at 1 to $14 \%$ for $C$. anisata and 8 to $15 \%$ for P. glandulosus (Table 4).
The essential oils studied showed a concentration-dependent antiradical activity by inhibiting DPPH radical with an $\mathrm{EC}_{50}$ value of $2.66 \mathrm{mg} / \mathrm{l}$ for $C$. anisata, $3.02 \mathrm{mg} / \mathrm{l}$ for $P$. glandulosus; that of BHT was $150 \mu \mathrm{g} / \mathrm{l}$ (Table 4). DPPH is usually used as a substrate to evaluate antioxidative activity of antioxidants (Oyaizu, 1986).

\section{Conjugated diene method}

Using the conjugated diene method, at various concentrations, the formulated essential oils showed an antioxidant activity which depended on the concentration of essential oils used and time of exposition (Figure 1). At $50{ }^{\circ} \mathrm{C}$, all concentrations of essential oils, BHT in corn oils were prooxidant and accelerated the formation of hydroperoxide at 300 and $1000 \mathrm{ppm}$ during two weeks of oxidation. The corn oil promoted hydroperoxide formation more strongly than the different concentration of essential oils except at $300 \mathrm{ppm}$ (Figure 1). BHT had lower prooxidant activity than these two essential oils tested at the same concentration. The essential oils and the corn oil showed a rapid formation of the hydroperoxides at $50{ }^{\circ} \mathrm{C}$ in the first two days of oxidation, with the $\mathrm{ET}_{50}$ of $22 \mathrm{~h} 12.2 \mathrm{~min}$ and $9 \mathrm{~h} 7.2 \mathrm{~min}$ on day one and day two, 
respectively. The formulation with essential oils showed that hydroperoxide formation was inhibited about $50 \%$ from 300 ppm fourth, corresponding to $6 \mu \mathrm{g}$ in the corn oil. The $\mathrm{ET}_{50}$ of the formulation with $C$. anisata varied from day 2 to day 8 at concentrations going from $300 \mathrm{ppm}$ to $1000 \mathrm{ppm}$. For $P$. glandulosus, at the same concentrations, the $\mathrm{ET}_{50}$ varied from day 3 to day 11 . The control showed the highest inhibition of hydroperoxide formation than both essential oils, with $\mathrm{ET}_{50}$ varying from day 5 to day 15 exposition at $50{ }^{\circ} \mathrm{C}$ observation. At the first four concentrations, the antioxidant activities of essential oils were comparable to that of BHT (Table 5).

\section{DISCUSSION}

The difference observed between the crude essential oils and those which were stored for 10 days at $28 \pm 2.2{ }^{\circ} \mathrm{C}$ temperature and $65 \pm 5.7 \%$ of relative humidity, although minimal, would be due to the fact that they first lost a little of their efficiency following the storage. This diminution of efficiency was due to the diminution of some compounds like sabinene, estragole, thymol, E-caryophyllene, germa-crene for $C$. anisata, and $\beta$ - myrcene, fenchone, $\alpha$-terpinolene, piperitenone oxide for $P$. glandulosus, due to the temperature and the relative humidity to which essential oils are exposed (Noudjou, 2007). Indeed, as oils are constituted in majority by volatile compounds, under the effect of the temperature, they are freed progressively (Goudoum, 2006). This reduction of the concentration, also drag the decrease of the efficiency of these compounds.

The results of different antioxidants tests showed that BHT, which is the synthetic antioxidant product had the highest activity compared to that of essential oils of $C$. anisata and $P$. glandulosus. The difference in activity of these antioxidant products was due to their different compound constitution. Goudoum (2002) showed that the persistence of insecticidal activity of both essential oils was 10 days in powder formulation, and 16 and 20 hours respectively for crude essential oils of $H$. spicigera and L. rugosa applied to filter paper (Goudoum, 2006).

As a result, $\beta$-carotene will be oxidized and broken down in part; subsequently, the system loses its chromophore and characteristic orange colour, which can be monitored spectrophotometrically (Kumaran \& karunakaran, 2007). The presence of different antioxidants can hinder the extent of $\beta$-carotene bleaching, by neutralising the linoleate-free radical and other free radicals formed in the system (Jayaprakasha et al., 2001). In our present study, the essential oils of $C$. anisata and $P$. glandulosus were found

Table 4: Antiradical activity of essential oils of crude and 10 days storage Clausena anisata and Plectranthus glandulosus observed with DPPH.

\begin{tabular}{|c|c|c|c|c|c|c|}
\hline & \multicolumn{5}{|c|}{ Inhibition $(\%)\left[\left(\mathbf{A 0}^{\circ}-\mathbf{A}^{\circ}\right)^{*} \mathbf{1 0 0} / \mathbf{A}^{\circ} \mathbf{0}\right]$} & \multirow[b]{2}{*}{$\begin{array}{c}\mathbf{E C}_{50} \\
\text { (10 days) }\end{array}$} \\
\hline & $\mathrm{C}(\mathrm{mg} / \mathrm{l})$ & Crude oil & 10 days aft & & \% Reduction & \\
\hline \multirow{5}{*}{ C. anisata } & 1 & $12.24 \pm 0.80$ & $11.25 \pm 0.36$ & $\mathrm{a}$ & 8.08 & $2.66 \mathrm{mg} / \mathrm{l}$ \\
\hline & 5 & $62.26 \pm 0.40$ & $55.38 \pm 0.51$ & $\mathrm{~b}$ & 11.05 & \\
\hline & 10 & $71.41 \pm 0.05$ & $61.44 \pm 0.83$ & $\mathrm{c}$ & 13.96 & \\
\hline & 15 & $72.19 \pm 0.36$ & $61.73 \pm 0.65$ & $\mathrm{~d}$ & 14.48 & \\
\hline & $F(3,4)$ & $6818.19 * * *$ & $8928.18 * * *$ & & & \\
\hline \multirow{5}{*}{ P. glandulosus } & 1 & $35.72 \pm 0.84$ & $32.31 \pm 0.71$ & $\bar{a}$ & 9.54 & $3.02 \mathrm{mg} / \mathrm{l}$ \\
\hline & 5 & $50.69 \pm 0.73$ & $48.56 \pm 0.44$ & $\mathrm{~b}$ & 4.20 & \\
\hline & 10 & $62.14 \pm 0.75$ & $52.12 \pm 0.24$ & $\mathrm{c}$ & 16.12 & \\
\hline & 15 & $63.31 \pm 0.30$ & $53,17 \pm 0.55$ & $\mathrm{~d}$ & 16.01 & \\
\hline & $F(3,4)$ & $744.27 * * *$ & $2716.5 * * *$ & & & \\
\hline \multirow{5}{*}{ BHT } & 0.1 & $48.80 \pm 0.11$ & $48.27 \pm 0.79$ & $\mathrm{a}$ & 1.08 & $150 \mu \mathrm{g} / \mathrm{l}$ \\
\hline & 0.5 & $51.56 \pm 0.15$ & $50.87 \pm 0.87$ & $\mathrm{~b}$ & 1.72 & \\
\hline & 1 & $62.23 \pm 0.14$ & $60.67 \pm 1.00$ & $\mathrm{c}$ & 2.50 & \\
\hline & 1.5 & $69.69 \pm 0.48$ & $68.94 \pm 0.81$ & $\mathrm{~d}$ & 1.07 & \\
\hline & $F(3,4)$ & $2596.74 * * *$ & $11070.29 * * *$ & & & \\
\hline
\end{tabular}

$\mathrm{EC}_{50}$ value is the effective concentration at which the absorbance was 0.5 for inhibiting DPPH radical. $* * *=$ Significant at $1 \%$., Mean values followed by the same letter in the same column do not differ significantly at $\mathrm{P}<0.0001$ (Duncan's test). 

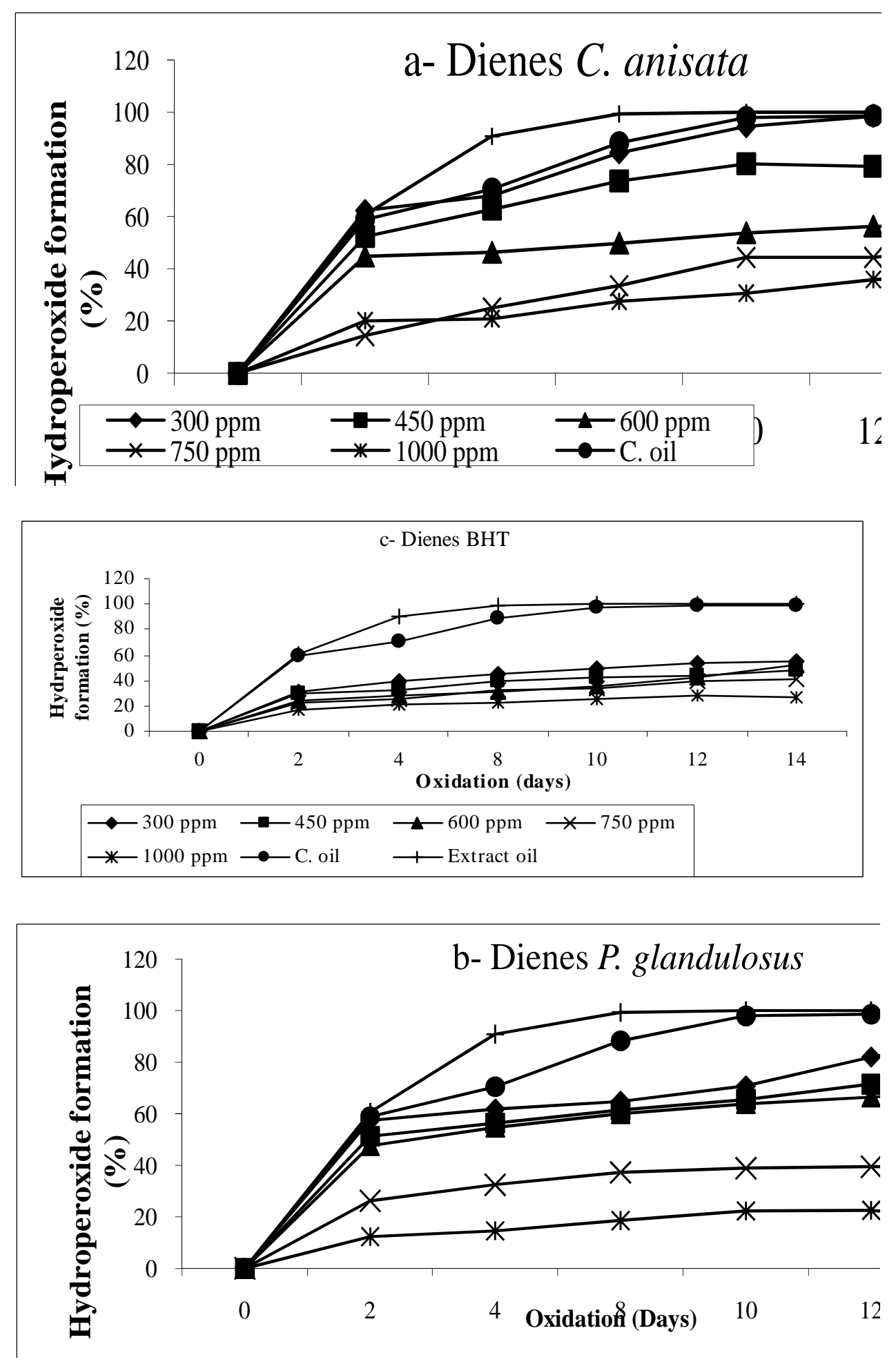

Figure 1: Effect of essentials oils Clausena anisata and Plectranthus glandulosus on oxidative stability of corn oil by measuring hydroperoxide formation at $50{ }^{\circ} \mathrm{C}$. 
Table 5: Value of effective time that the 50\% of antioxidant activity was obtained.

\begin{tabular}{lcccccc} 
& \multicolumn{5}{c}{ ET $_{\mathbf{5 0}}$} \\
\cline { 2 - 7 } Concentrations & C. anisata & P. glandulosus & BHT \\
\hline $300 \mathrm{ppm}$ & $2 \mathrm{~d} 9 \mathrm{~h} 50.4 \mathrm{mn}$ & $\mathrm{a}$ & $3 \mathrm{~d} 14 \mathrm{~h} 24 \mathrm{mn}$ & $\mathrm{a}$ & $5 \mathrm{~d} 9 \mathrm{~h} 7.2 \mathrm{mn}$ & $\mathrm{a}$ \\
$450 \mathrm{ppm}$ & $3 \mathrm{~d}$ & $\mathrm{a}$ & $3 \mathrm{~d} 12 \mathrm{~h} 14.4 \mathrm{mn}$ & $\mathrm{a}$ & $6 \mathrm{~d} 12 \mathrm{~h}$ & $\mathrm{a}$ \\
$600 \mathrm{ppm}$ & $4 \mathrm{~d} 20 \mathrm{~h} 52.8 \mathrm{mn}$ & $\mathrm{b}$ & $3 \mathrm{~d} 19 \mathrm{~h} 12 \mathrm{mn}$ & $\mathrm{a}$ & $6 \mathrm{~d} 16 \mathrm{~h} 19.2 \mathrm{mn}$ & $\mathrm{a}$ \\
$750 \mathrm{ppm}$ & $6 \mathrm{~d} 11 \mathrm{~h} 31.2 \mathrm{mn}$ & $\mathrm{b}$ & $7 \mathrm{~d} 15 \mathrm{~h} 7.2 \mathrm{mn}$ & $\mathrm{b}$ & $7 \mathrm{~d} 17 \mathrm{~h} 16.8 \mathrm{mn}$ & $\mathrm{a}$ \\
$1000 \mathrm{ppm}$ & $8 \mathrm{~d} 12 \mathrm{~h} 28.8 \mathrm{mn}$ & $\mathrm{b}$ & $11 \mathrm{~d} 15 \mathrm{~h} 7.2 \mathrm{mn}$ & $\mathrm{c}$ & $15 \mathrm{~d} 11 \mathrm{~h} 16.8 \mathrm{mn}$ & $\mathrm{b}$ \\
\hline$X^{2}(1,4)$ & $5.00 *$ & & $9.12 *$ & & $2.96 *$ & \\
\hline
\end{tabular}

$\mathrm{ET}_{50}$ value is the effective time at which the antioxidant activity was $50 \%$ and was obtained. $* * *=$ Significant at $1 \% 0$. , Mean values followed by the same letter in the same column do not differ significantly at $\mathrm{P}<0.05$ (Duncan's test).

to hinder the extent of $\beta$-carotene bleaching by neutralizing the linoleate free radical and other free radicals formed in the system.

Previous works (Tanaka et al., 1988; Pin-Der-Duh, 1998; Pin-Der-Duh et al., 1999) pointed out direct correlation between antioxidant activities and reducing power of certain plant extracts. The reducing properties are generally associated with the presence of reductones (Pin-Der-Duh, 1998), which have been shown to exert antioxidant action by breaking the free radical chain by donating a hydrogen atom (Gordon, 1990). Reductones are also reported to react with certain precursors of peroxide, thus preventing peroxide formation. Our data on the reducing power of essential oils suggest that it contributes significantly to the observed antioxidant effect. However, the antioxidant activity of antioxidants have been attributed to various mechanisms, among which are prevention of chain initiation, binding of transition metal ion catalysts, decomposition of peroxides, prevention of continued hydrogen abstraction, reductive capacity and radical scavenging (Diplock, 1997). Like the antioxidant activity, the reducing power of essential oils increased with increasing amount of sample. However, the reducing power of BHT was more pronounced than that of essential oils.

The DPPH method is based on the reduction of methanolic DPPH solution in the presence of a hydrogen donating antioxidant, due to the formation of the non-radical form DPPH-H by the reaction. The essential oils studied were able to reduce the stable radical DPPH to the yellow-coloured diphenylpicrylhydrazine. It has been found that cysteine, glutathione, ascorbic acid, tocopherol, polyhydroxy aromatic compounds, and aromatic amines, reduce and decolourise 1,1-diphenyl-2-picrylhydrazyl by their hydrogen donating ability (Blois, 1958). It appears that the essential oils possess hydrogen donating capabilities and act as antioxidants. The scavenging effect increased with increasing concentration of the essential oils. However, scavenging activity of BHT, a known antioxidant, used as positive control, was relatively more pronounced than that of essential oils.

The results of the conjugated dienes method showed that essential oils of $C$. anisata and $P$. glandulosus were all antioxidants in corn oil. The antioxidant activity of these two essential oils may be related to their hydrogen-donating ability. The lower potential and easier formation of radicals indicate the higher hydrogen-donating ability of antioxidants (Huang et al., 1995; Huang \& Frankel, 1997). On the basis of their ease of radical formation, high concentrations showed better hydrogen donors than the lower concentrations. Similar studies done on methanolic extracts from olive (Chimi et al., 1991), from tea catechins (Huang and Frankel, 1997), from polished rice (Tseng et al., 2003), from Maydis stigma (Maksimovic, 2005), from Monascal adlay (Tseng et al., 2007) and from C. anisata (Avlessi et al., 2004) showed moderate antioxidant activity.

The essential oils of $C$. anisata and $P$. glandulosus leaves exhibited different levels of antioxidant activity after 10 days of storage in food in all the models studied. The results from various free radical-scavenging systems revealed that the $C$. anisata and $P$. 
glandulosus had significant antioxidant activity and free radical-scavenging activity. The free radical-scavenging property may be one of the mechanisms through which this drug is useful as a foodstuff preservation substance, as well as a traditional medicine. These antioxidant activities, although weak compared to the BHT one, could be all the same beneficial to the consumers of storage products to which they are used.

\section{REFERENCES}

Anonyme. 2004. Storeprotect, Rapport semestriel Année U.N. (période septembre 2003-février 2004).

Avlessi F, Dangou J, Wotto VD, Alitonou GA, Sohounhloue DK, Menut C. 2004. Propriétés antioxydantes de l'huile essentielle des feuilles de Clausena anisata (Wild) Hook. C. R. Chim., 7: 1057-1061.

Blois MS. 1958. Antioxidants determination by the use of a stable free radical. Nature, 4617: 1199-1200.

Braca A, Tommasi ND, Bari LD, Pizza C, Politi M, Morelli I. 2001. Antioxidant principles from Bauhinia terapotensis. $J$. Nat. Prod., 64: 892-895.

Chimi H, Cillard J, Rahmani J. 1991. Peroxyl and hydroxyl radical scavenging activity of some natural phenolic antioxidants. $J$. Am. Oil Chem. Soc., 68(5): 307-312.

CIRAD. 2007. Unité de recherche : Démarche intégrée pour l'obtention d'aliments de qualité. http://umr-qualisud.cirad.fr/projet -de-recherche.

Davies NW. 1990. Gas chromatographic retention indices of monoterpenes and sesquiterpenes on methyl silicone and carbowax 20M phases. J. Chromatogr., 503: $1-24$.

Diplock AT. 1997. Will the good fairies please prove us that vitamin E lessens human degenerative disease? Free Radical Res., 27: 511-532.

Frankel EN, Huang SW, Kanner J, German JB. 1994. Interfacial phenomena in the evaluation of antioxidants: bulk oils versus emulsions. J. Agric. Food. Chem., 42: 1054-1059.

Goudoum A. 2002. Recherche de la rémanence de l'activité insecticide de six huiles essentielles sur Sitophilus zeamais Motsch. (Coleoptera: Curculionidae).
Mémoire de maîtrise, Université de Ngaoundéré, $47 \mathrm{p}$.

Goudoum A. 2006. Résistance de Tribolium castaneum Herbst (Coleoptera: Tenebrionidae) et Sitophilus zeamais Motsch. (Coleoptera : Curculionidae) au lindane et au fipronil et sensibilité de ces ravageurs à trois huiles essentielles. Mémoire de D.E.A., ENSAI, Université de Ngaoundéré, 91p.

Goudoum A, Ngamo LST, Ngassoum MB, Tatsadjieu NL, Mbofung CM. Tribolium castaneum sensitivity to repetitive applications of lethal doses of imidacloprid Clausena anisata and Plectranthus grandulosus. C.A.J.E.B. MS 6313. (In press).

Gordon MH. 1990. The mechanism of antioxidant action in vitro. In Food Antioxidants, Hudson BJF (ed). Appl. Sci. Res. : London; 1-18.

Huang SW, Frankel EN. 1997. Antioxidant activity of Tea catechins in different lipid systems. J. Agric. Food. Chem., 45: 3033-3038.

Huang SW, Frankel EN, German JB. 1995. Antioxidant activity of $\alpha$ - and $\gamma$ tocopherols in bulk oils and in oil-inwater emulsions. J. Agric. Food. Chem., 42: $2108-2114$.

Huang Y, Tan JMW, Kini RM, Ho SH. 1997. Toxic and antifeedant action of Nutmeg oil against Tribolium cataneum (Herbst) and Sitophilus zeamais Motsch. J. Stored Prod. Res., 33(4): 289-298.

Jayaprakasha GK, Singh RP, Sakariah KK. 2001. Antioxidant activity of grape seed (Vitis vinifera) extracts on peroxidation models in vitro. Food Chem., 73: 285290.

Kouroussou R, Lanara T, Kokkini S. 1998. Piperitone oxide-rich essential oils from Mentha longifolia subsp. petiolata and M. $\mathrm{x}$ villoso-nerveta grown on the Island of Crete (S. Greece). J. Essent. Oil Res., 10: 375-379.

Kumaran A, karunakaran J. 2007. Antioxidant and free radical scavenging activity of an aqueous extract of Coleus aromaticus. Food Chem., 100(1): 356-365.

Maksimovic Z, Malencic, Kovacevic N. 2005. Polyphenol contents and antioxidant activity of Maydis stigma extracts. Biores. Techn., 96: 873-877. 
Miller HE. 1971. A simplified method for the evaluation of antioxidant. J. Am. Oil Chem. Soc., 18: 439-452.

Noudjou WFE. 2007. Utilisation des huiles essentielles pour la protection des grains contre les insectes ravageurs au Nord du Cameroun. Thèse de Ph.D, Faculté Universitaire des Sciences Agronomiques de Gembloux (Belgique), 200p.

Oyaizu M. 1986. Studies on product of browning reaction prepared from glucose amine. Jpn. J. Nutri., 44: 307-315.

Pin-Der-Duh X. 1998. Antioxidant activity of burdock (Arctium lappa Linne): its scavenging effect on free-radical and active oxygen. J. Am. Oil Chem. Soc., 75: 455-461.

Pin-Der-Duh X, Pin-Chan-Du X, Gow-Chin Yen X. 1999. Action of methanolic extract of mung hulls as inhibitors of lipid peroxidation and non-lipid oxidative damage. Food Chem. Toxicol., 37: 10551061.
Regnault-Roger C, Philogène BJR, Vincent C. 2002. Biopesticides d'Origines Végétales. Tec and Doc Eds: Paris; 337p.

Tanaka M, Kuie CW, Nagashima Y, Taguchi T. 1988. Applications of antioxidative Maillard reaction products from histidine and glucose to sardine products. Nippon Suisan Gakkaishi, 54: 1409-1414.

Tseng YH, Lee YL, Yang JH, Mau JL. 2003. Evaluation of antioxidant properties of Monascus purpureus-fermented rice. In $41^{\text {st }}$ Ann. Meet. Chin. Agric. Chem. Soc., Taipei. Editeurs.

Tseng YH, Yang JH, Chang HL, Lee YL, Mau JL. 2007. Antioxidant properties of methanolic extracts from monascal adlay. Food Chem., 97(3): 375-381.

White, Leesch. 1995. Chemical Control. Integrated Management of Insects in Store Products. Dekker, Inc: New York, Basel. Hong Kong; 287-330. 